\title{
How Much Do Routine Blood Tests Tell Us About Patent Ductus Arteriosus? Is the Red Cell Distribution Width to Platelet Count Ratio or/and Any Platelet Parameter Useful?
}

\section{Birol Karabulut1, ๑ Ayşe Şimşek²}

1İzmir Katip Çelebi University, Atatürk Training and Research Hospital, Clinic of Pediatrics, Division of Neonatology, İzmir, Turkey

${ }^{2}$ Buca Women and Children Diseases Hospital, Clinic of Pediatric Cardiology, İzmir, Turkey

\begin{abstract}
Objectives: In this observational study, to determine whether there is any association between red cell distribution width (RDW)/platelet count ratio (RPR) and hemodynamically significant patent ductus arteriosus (hsPDA) in preterms.

Materials and Methods: A total of 233 preterm infants, gestational age $<34$ weeks were analyzed in the study. Complete blood counts obtained at $24^{\text {th }} \mathrm{h}, 48^{\text {th }} \mathrm{h}, 72^{\text {nd }} \mathrm{h}$ and 7 th days were evaluated for RDW, RPR, platelet parameters and compared for PDA status.

Results: Our study included 64 infants with hsPDA and

64 controls. The RDW at $48^{\text {th }} \mathrm{h}, 72^{\text {nd }} \mathrm{h}$, and 7 th day and the RPR at $24^{\text {th }} \mathrm{h}, 4^{\text {th }} \mathrm{h}, 7^{\text {nd }} \mathrm{h}$ and $7^{\text {th }}$ day were significantly higher in the study compared to the control group; the PCT was lower. The RPR afforded $72.3-79.2 \%$ sensitivity and 82.3-89.2\% specificity when used to predict hsPDA.

Conclusion: None of platelet count, PDW, mean platelet volume, or Platelet Mass index can be used to predict either hsPDA or treatment success, but a low PCT, and a high RDW and RPR, predict hsPDA but not treatment success.

Keywords: Patent ductus arteriosus, red cell distribution width, platelet count, ratio
\end{abstract}

\footnotetext{
Address for Correspondence: Birol Karabulut, İzmir Katip Çelebi University, Atatürk Training and Research Hospital, Clinic of Pediatrics, Division of Neonatology, İzmir, Turkey

e-mail: dr.birolkarabulut@icloud.com ORCID: orcid.org/0000-0003-0523-153X

Received: 23.04.2020 Accepted: 12.05.2020

Cite this article as: Karabulut B, Şimşek A. How Much Do Routine Blood Tests Tell Us About Patent Ductus Arteriosus? Is the Red Cell Distribution Width to Platelet Count Ratio or/and Any Platelet Parameter Useful? EJCM 2020;8(2):91-98.

DOI: 10.32596/ejcm.galenos.2020.04.020
}

${ }^{\circ}$ Copyright 2020 by Heart and Health Foundation of Turkey (TÜSAV) / E Journal of Cardiovascular Medicine published by Galenos Publishing House. 


\section{Introduction}

The ductus arteriosus (DA), situated between the aortic arch and the pulmonary artery in the foetal circulation, closes within a few hours after birth; this is one of the most important changes required for the transition to extrauterine life ${ }^{(1-3)}$. A prolonged duration of DA patency increases left-to-right shunting, lung blood flow, and left ventricular volume loading, and decreases systemic perfusion. Although many studies on Doppler echocardiography (the principal PDA diagnostic method) have appeared, there is, as yet, no consensus on hsPDA diagnosis or how to predict morbidity and mortality ${ }^{(4-6)}$. Therefore, we sought new diagnostic methods identifying hsPDA prior to leftto-right shunting, increases in lung blood flow and left ventricular volume loading, and the decrease in systemic perfusion. Earlier, recognizing that platelets have important affects in many inflammatory events such as acute and chronic infection, malignancy, and wound-healing ${ }^{(7,8)}$, Echtler et al. ${ }^{(9)}$ studied the relationship between ductal closure and platelet levels in animals; this level correlated negatively with inflammation. Platelets played an important role in duct closure, becoming attached to the lumen of the DA a few minutes after birth. In the same study, the DA did not close (thus, remained permanently open) in animals in which platelet functions were compromised. Studies on premature infants followed. Mean platelet volume (MPV), platelet count, and platelet distribution width (PDW) were investigated; a low platelet count and a low PDW were risk factors for PDA ${ }^{(10-11)}$. No clear relationship was evident between the platelet mass index and ductal closure ${ }^{(12,13)}$. As the reported effects of platelet numbers were contradictory, other parameters that might aid hsPDA diagnosis were investigated. We hypothesized that inflammation might inhibit ductal closure. The red cell distribution width (RDW) and the $\mathrm{RDW} /$ platelet count ratio (RPR), a proven measure of inflammation in adults, would both be high in preterm infants with hsPDA ${ }^{(14,15)}$.

\section{Materials and Methods}

\section{Patients}

This observational study was conducted between 2016 and 2018. We calculated total sample size of 128 in the study and 64 in the control group $(d=0.5$; power $=80 \%$; $\alpha=0.05)^{(16)}$. We examined the medical records of newborns admitted to our tertiary neonatal intensive care unit. Preterm infants of gestational age $<34$ weeks were included in the study; we calculated gestational age by reference to the mother's last menstrual date or on the basis of ultrasonography performed before 20 weeks. We excluded infants of unknown gestational age, those with conditions that might cause inflammation or affect platelet count and/or function and lack of data (Figure 1).

\section{PDA Diagnosis}

Echocardiography was performed on preterm infants at the time of clinical findings or within 24-72 $\mathrm{h}$ after admission. hsPDA associated clinical findings were

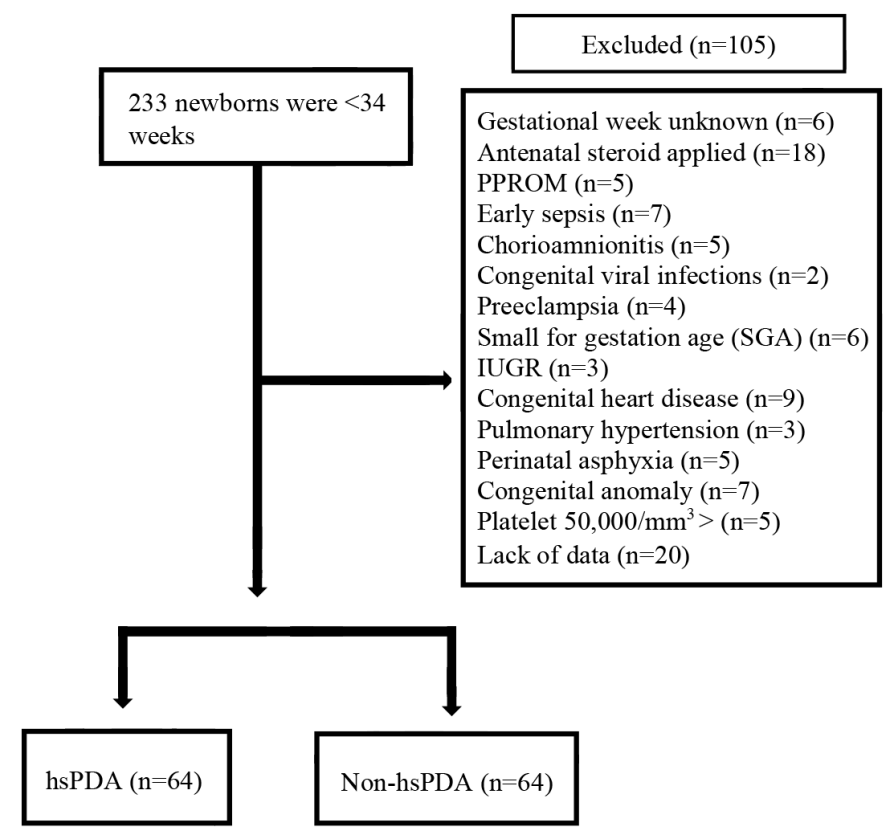

Figure 1. Flowchart of study group

PPROM: Preterm premature rupture of the membranes, IUGR: Intrauterine growth restriction, hsPDA: Hemodynamically significant patent ductus arteriosus 
murmur, tachycardia, hypotension, oliguria, and increased respiratory distress. hsPDA's echocardiographic findings were ductal diameter $\geq 1.5 \mathrm{~mm}$, left atrium/aortic root ratio $\geq 1.5$, and/or diastolic flow failure or inverse flow in the abdominal aorta. Echocardiography was performed at the end of the medical treatment and the DA was classified as closed or open. The preterms were divided into two groups. Those with hsDPA who underwent ductus closure treatment constituted Group 1; those lacking hsPDA formed Group 2.

\section{PDA Treatment}

In our unit, we employ intravenous or oral ibuprofen to close the ducts of preterm infants exhibiting hemodynamically significant PDA. Intravenous or oral paracetamol are given if ibuprofen is unsuccessful or contraindicated $^{(17,18)}$. Ibuprofen (Dolven $100 \mathrm{mg}$, Sanofi) was administered at $10 \mathrm{mg} / \mathrm{kg}$ on day 1 , and at $5 \mathrm{mg} / \mathrm{kg}$ on days 2 and 3; paracetamol (Parol $10 \mathrm{mg} / \mathrm{mL}$ solution) was administered at $15 \mathrm{mg} / \mathrm{kg}$ every $6 \mathrm{~h}$ for 3 days. If DA was open, the second course was given.

\section{Platelet Parameters}

Blood samples taken from an umbilical venous catheter at the $24^{\text {th }}, 48^{\text {th }}$ and $72^{\text {nd }}$ hours, and at day 7 were collected in ethylenediaminetetraacetic acid-containing tubes and blood counts performed via Coulter Counter (FL, USA). This yielded the platelet count and the MPV, PDW, PCT, and RDW. The Platelet Mass index was obtained from the platelet count $\left(10^{3} / \mathrm{mm}^{3}\right)$ and the MPV (fL); the RPR was the ratio of the RDW to the platelet count.

\section{Data Collection}

We recorded gestational age, birth weight, sex, mode of delivery, Apgar scores (at the first and fifth minute), $24^{\text {th }}, 48^{\text {th }}$ and $72^{\text {nd }}$ hours, and at day 7 hemographic parameters, any surfactant requirement, ventilation history, the intraventricular hemorrhage, PVL, necrotizing enterocolitis, retinopathy of prematurity, and Bronchopulmonary dysplasia (BPD), duration of hospitalization and any death. The primary outcome was whether the RDW and/or RPR could be used to predict hsPDA diagnosis and treatment success.

\section{Statistical Analysis}

Statistical analyses were performed using SPSS 22.0. The t-test and Mann-Whitney U test were used to compare. A p-value less than 0.05 was considered statistically significant. The cut-off value, sensitivity and specificity of the RPR were calculated using a receiver operator curve.

\section{Results}

Two hundred and thirty-three premature infants less than 34 weeks of gestational age were admitted to NICU and 105 premature infants were excluded from the study. The study group consisted of 64 hsDPA patients who underwent closure treatment and 64 with no hsDPA or a closed PDA constituted the control group (Figure 1). The demographic variables of the groups were shown in Table 1. Sixty-four premature infants with hsPDA were administered medical treatment, 51 premature infants' DAs were detected closed after the first course and 13 premature infants were required second course and none of premature infants required surgical closure. The hematological parameters of the groups were shown in Table 2. RDW values at the $48^{\text {th }} \mathrm{h}, 72^{\text {nd }} \mathrm{h}$, and $7^{\text {th }}$ day and RPR values at the $24^{\text {th }}, 48^{\text {th }}$ and $72^{\text {nd }}$ hours, and at day 7 were significantly higher in the study group. We

Table 1. Comparison of demographic characteristics of the hsPDA and Non-hsPDA groups

\begin{tabular}{|c|c|c|c|}
\hline Characteristics & $\begin{array}{l}\text { hsPDA } \\
(n=64)\end{array}$ & $\begin{array}{l}\text { Non- } \\
\text { hsPDA } \\
(n=64)\end{array}$ & $p$ value \\
\hline GA, week (mean \pm SD) & $29.4 \pm 3.6$ & $30.1 \pm 4.2$ & 0.166 \\
\hline BW, g (mean \pm SD) & $1226 \pm 109$ & $1317 \pm 168$ & 0.104 \\
\hline Male, $\mathrm{n}(\%)$ & $37(57.8)$ & $33(51.5)$ & 0.092 \\
\hline C/S, n (\%) & $29(45.3)$ & $18(28.1)$ & 0.077 \\
\hline \multicolumn{4}{|c|}{ Apgar score, medians (min-max) } \\
\hline First minute & $6(4-8)$ & $7(4-8)$ & 0.144 \\
\hline Fifth minute & $7(5-9)$ & $8(5-9)$ & 0.168 \\
\hline
\end{tabular}




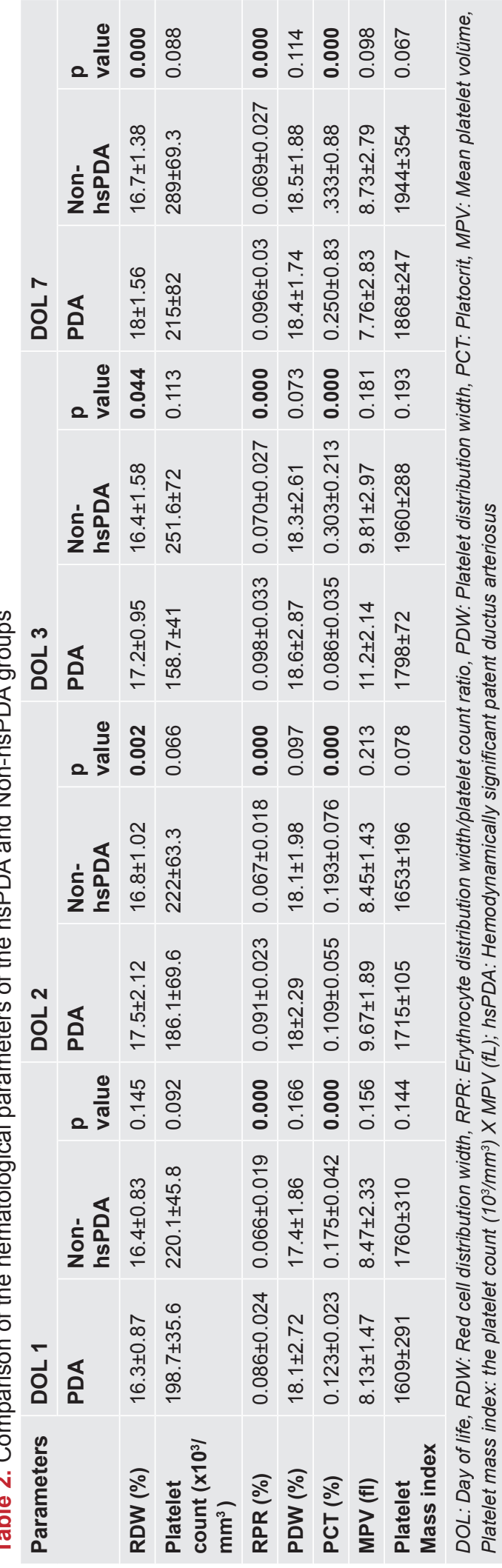

calculated cutoff value, sensitivity and specificity, positive and negative predictive values of RPR (Table 3). RPR afforded $72.3-79.2 \%$ sensitivity and $82.3-89.2 \%$ specificity when used to predict hsPDA. However, there was no difference between the groups in the hematological parameters of the preterm infants with closed DAs and the 13 preterm infants with open DAs after the first treatment. In other words, none of the RPR, RDW, or platelet count could be used to predict the response to treatment (Table 4). When the complications of prematurity of the groups were compared, surfactant requirement, pulmonary hemorrhage, steroid requirement to treat $\mathrm{BPD}$, total duration of ventilation, and the BPD were detected more frequently in the study group (Table 5).

\section{Discussion}

The principal factors of the DA continuity in intrauterin life are decreased oxygen concentration, increased prostaglandin and nitric oxide. After birth, increased oxygen concentration and decreased prostaglandin enable DA's functional closure ${ }^{(19)}$. Moreover, various suggestions have been made about DA closure physiology. The discussion began when Echtler et al. ${ }^{(9)}$ showed that platelets were attached to the lumen of the closed DA and confirmed this experimental finding via a retrospective study of preterm births. After this animal study, various hypotheses about the role played by platelets in duct closure in newborns have been proposed. The most accepted hypothesis is that platelets affect on DA contraction, decreasing the blood flow in the venous lumen and vasa vasorum cause hypoxia in the vessel wall which occurs immediately after birth in term neonates; in preterm neonates, the cells of the ductus vessel wall are fed by the vessel lumen because of the absence of a vasa vasorum. As the ductus vessel wall is thin, contraction is inadequate, and hypoxia causes endothelial damage and platelet aggregation. Therefore, it was speculated that platelet functions were important regarding of DA closure in preterm infants ${ }^{(20,21)}$. Despite that, this hypothesis is not sustained in some studies. These studies have reported that platelet transfusion does not reduce the frequency of the PDA in preterm infants with immune thrombocytopenia ${ }^{(22,23)}$. In our study, no difference was found between the platelet counts of the groups. In addition, there was no difference between the platelet counts of patients who did and did not fail treatment. In conclusion, the platelet count was 
Table 3. ROC curve analysis of the RPR between hsPDA and non-hsPDA groups

\begin{tabular}{|l|l|l|l|l|l|l|l|}
\hline Parameters & Cut-off value & AUC \% & Sensitivity \% & Specificity \% & LR+ & PPV \% & NPV \% \\
\hline RPR at 24.hours & 0.735 & 0.746 & 72.3 & 82.3 & 4.08 & 80.3 & 74.8 \\
\hline RPR at 48.hours & 0.735 & 0.779 & 74.6 & 85.4 & 5.10 & 83.6 & 77.1 \\
\hline RPR at 72.hours & 0.795 & 0.786 & 79.2 & 89.2 & 7.35 & 88 & 81.1 \\
\hline RPR at 7th day & 0.830 & 0.789 & 76.2 & 91.5 & 9 & 89.9 & 79.3 \\
\hline
\end{tabular}

RPR: Erythrocyte distribution width/platelet count ratio, AUC: Area under curve, LR+, Likelihood ratio, PPV: Positive predictive value, NPV: Negative predictive value, ROC: Receiver operating characteristic

Table 4. Comparison of study groups in terms of hematological parameters before and after treatment

\begin{tabular}{|c|c|c|c|}
\hline Parameters & $\begin{array}{l}\text { Closed PDA } \\
(n=51)\end{array}$ & $\begin{array}{l}\text { Open PDA } \\
(n=13)\end{array}$ & $p$ value \\
\hline RDW \% & $17.1 \pm 3.67$ & $17.8 \pm 4.12$ & 0.137 \\
\hline $\begin{array}{l}\text { Platelet count } \\
\left(\times 10^{3} / \mathrm{mm}^{3}\right)\end{array}$ & $223 \pm 56$ & $198 \pm 44$ & 0.099 \\
\hline RPR \% & $0.091 \pm 0.026$ & $.096 \pm 0.03$ & 0.114 \\
\hline PDW \% & $18.3 \pm 3.17$ & $19.1 \pm 4.26$ & 0.235 \\
\hline РСТ \% & $0.185 \pm 0.041$ & $0.138 \pm 0.037$ & 0.086 \\
\hline MPV (fl) & $7.84 \pm 2.23$ & $7.13 \pm 1.98$ & 0.134 \\
\hline $\begin{array}{l}\text { Platelet mass } \\
\text { index }\end{array}$ & $1765 \pm 437$ & $1629 \pm 383$ & 0.185 \\
\hline \multicolumn{4}{|c|}{$\begin{array}{l}R D W: \text { Red cell distribution width, RPR: Erythrocyte distribution width/ } \\
\text { platelet count ratio, PDW: Platelet distribution width, PCT: Platocrit, MPV: } \\
\text { Mean platelet volume, Platelet mass index: the platelet count }\left(10^{3} / \mathrm{mm}^{3}\right) \times \\
\text { MPV (fL) }\end{array}$} \\
\hline
\end{tabular}

not a predictor of hsPDA diagnosis or treatment success. The results of our study contradict those of the two major meta-analyses conducted by Simon et al. ${ }^{(24)}$ and Mitra et al. ${ }^{(25)}$, but support the cohort study of Sallmon et al. ${ }^{(26)}$.

Shah et al. ${ }^{(11)}$, Kahvecioglu et al. ${ }^{(13)}$, Fujioka et al. ${ }^{(27)}$, Bekmez et al. ${ }^{(28)}$, Bas-Suarez et al. ${ }^{(29)}$, Murphy et al. ${ }^{(30)}$ and Brunner et al. ${ }^{(31)}$ reported that platelet count was not related to PDA diagnosis or treatment success. On the other hand, Echtler et al..$^{(9)}$, Kulkarni et al. ${ }^{(32)}$ and Meinarde et al. ${ }^{(33)}$ reported that a low platelet count increased the hsPDA frequency. In some studies performed after these contradictory studies, it was reported that large platelets create a greater potential risk of prothrombotic reactions; large platelets are more aggregated than small and normal platelets given the greater number of receptors such as thromboxane A2-B2 and glycoproteins IIb-IIIa on the surfaces of large platelets. It was suggested that the increased metabolic and enzymatic activities of dysfunctional thrombocytes, rather than the platelet count, were associated with $\mathrm{PDA}^{(34-38)}$. We sought to identify parameters related to platelet function associated with PDA. These remain controversial; all of MPV, PDW, PCT, and platelet mass index have been associated with cardiovascular diseases in adults ${ }^{(39-44)}$. In addition, in a limited number of studies on neonates, the MPV and PDW were shown to be associated with prematurity complications such as RDS and $\mathrm{BPD}^{(45-47)}$. In our study, the difference between the PCT levels of the hsPDA and control groups was statistically significant. The MPV and platelet mass index values were similar in both groups. Thus, we conclude that the PCT can be used to predict hsPDA but not treatment success. Demirel et al. ${ }^{(48)}$ reported that the PDW was higher in preterm infants with hsPDA than in control groups. Bekmez et al. ${ }^{(28)}$ reported that a low PCT increased the hsPDA incidence. Demir et al. ${ }^{(49)}$ found a high MPV and a low platelet mass in the hsPDA group. In contrast, none of MPV, platelet mass, PDW, or PCT differed between the hsPDA and control groups of many studies ${ }^{(13,14,30,46,50)}$. Inflammation caused by hypoxia and oxidative stress plays an important role in DA closure; inflammation inhibited platelet aggregation by increasing cyclooxygenase activity and prostaglandin synthesis ${ }^{(51)}$. However, Olsson et al. ${ }^{(52)}$, in a study on 47 preterms 22-27 weeks of gestational age, found that BNP, NT-proBNP, PDGF, IL-6, IL-8, and IL-10 levels were high in hsPDA patients and an inflammatory indicator could be used to predict hsPDA persistence and treatment failure. In addition, it has been suggested that the RDW and the RPR, which have been associated with hypoxia and inflammation, may be useful markers of $\mathrm{PDA}^{(51-54)}$. 
Table 5. Comparison of the prematurity complications of the hsPDA and non-hsPDA groups

\begin{tabular}{|c|c|c|c|}
\hline Characteristics & $\begin{array}{l}\text { hsPDA } \\
(n=64)\end{array}$ & $\begin{array}{l}\text { Non-hsPDA } \\
(n=64)\end{array}$ & $p$ value \\
\hline \multicolumn{4}{|l|}{ Respiratory outcome } \\
\hline $\begin{array}{l}\text { Received surfactant, } n \\
(\%)\end{array}$ & $49(76.5)$ & $37(57.8)$ & 0.012 \\
\hline $\begin{array}{l}\text { Pulmonary hemorrhage, } \\
\text { n (\%) }\end{array}$ & $7(10.9)$ & $2(3.1)$ & 0.023 \\
\hline Pneumothorax, n (\%) & $3(4.6)$ & $2(3.1)$ & 0.122 \\
\hline $\begin{array}{l}\text { Duration of mechanical } \\
\text { ventilation, days (mean } \\
\pm \text { SD) }\end{array}$ & $40.8 \pm 4.6$ & $25.1 \pm 5.3$ & 0.014 \\
\hline $\begin{array}{l}\text { Postnatal steroid use for } \\
\text { BPD, } n(\%)\end{array}$ & $14(21.8)$ & $4(6.2)$ & 0.003 \\
\hline \multicolumn{4}{|l|}{ Clinical outcome } \\
\hline IVH, Grade 3-4, n (\%) & $7(10.9)$ & $6(9.3)$ & 0.162 \\
\hline NEC, Grade 2-3, n (\%) & $9(14)$ & $6(9.3)$ & 0.092 \\
\hline BPD, n (\%) & $9(14)$ & $3(4.6)$ & 0.011 \\
\hline ROP, n (\%) & $5(7.8)$ & $3(4.6)$ & 0.214 \\
\hline $\begin{array}{l}\text { Duration of } \\
\text { hospitalization } \\
\text { (mean } \pm \text { SD) }\end{array}$ & $66.3 \pm 9.5$ & $51.2 \pm 4.4$ & 0.033 \\
\hline Death, n (\%) & $3(4.6)$ & $1(1.5)$ & 0.124 \\
\hline
\end{tabular}

The primary aim of our study was to investigate whether the RDW and the RPR predicted PDA. In our study, the RDW and RPR values were significantly higher in hsPDA patients than in the control group. Bekmez et al. ${ }^{(28)}$ reported that although no RDW difference was evident between the study and control groups, the RPR was higher in the study group. Strengths of our study are that we calculated the required sample size using a statistical program, applied rigid exclusion criteria and tried to homogenize our sample group. We excluded infants with sepsis because this might affect platelet count and function, and might trigger erythropoiesis caused by inflammation and cytokine release ${ }^{(51,54)}$. We also excluded patients who received ibuprofen as ductus closure therapy because of potential effects on platelet count and functions. Infants born to mothers with prior preeclampsia, which affects platelet count and ductal flow because of the increased placental resistance, were also excluded ${ }^{(55-57)}$. We also excluded infants with perinatal asphyxia associated with an increased PDA, thrombocytopenia, and platelet dysfunction ${ }^{(58-60)}$. Newborns whose mothers had earlier received steroids were excluded because of possible effects on the platelet count. We thus excluded all pathologies that may affect platelet count and function and induce inflammation. We evaluated platelet count and function of preterms before and after the medical treatment. We diagnosed hsPDA according to both echocardiographic and clinical findings because of significant numbers of hsPDAs close spontaneously.

\section{Study Limitations}

We believe that our results are reliable and contribute significantly to the literature. However, there are some limitations of the study. The first is its retrospective nature. Although we excluded sepsis, simultaneous disease caused by inflammation may have affected the results of the study. The third limitation is that gestational age of preterm infants included in the study were $<34$ weeks, it was not less.

\section{Conclusion}

None of platelet count, PDW, MPV, or platelet mass index can be used to predict either hsPDA or treatment success, but a low PCT and a high RDW and RPR predict hsPDA but not treatment success.

\section{Ethics}

Ethics Committee Approval: This study is observational and retrospective nature.

Informed Consent: This study is observational and retrospective nature.

Peer-review: Internally and externally peer-reviewed.

\section{Authorship Contributions}

Concept: B.K., A.Ş., Design: B.K., A.Ş., Data Collection or Processing: B.K., A.Ş., Analysis or Interpretation: B.K., A.Ş., Literature Search: B.K., A.Ş., Writing: B.K., A.Ş. 
Conflict of Interest: No conflict of interest was declared by the authors.

Financial Disclosure: No funding was available for this study.

\section{References}

1. Clyman RI. Mechanisms regulating the ductus arteriosus. Biol Neonate 2006;89:330-5.

2. Weinberg JG, Evans FJ, Burns KM, Pearson GD, Kaltman JR. Surgical ligation of patent ductus arteriosus in premature infants: trends and practice variation. Cardiol Young 2016;26:1107-14

3. Mirea L, Sankaran K, Seshia M, et al. Treatment of patent ductus arteriosus and neonatal mortality/morbidities: Adjustment for treatment selection bias. J Pediatr 2012;161:689-94.e1.

4. Sehgal A, McNamara PJ. The ductus arteriosus: A refined approach!. Semin Perinatol 2012;36:105-13.

5. Evans N. Preterm patent ductus arteriosus: A contnuing conundrum for the neonatologist?. Semin Fetal Neonatal Med 2015;20:272-7.

6. Smith A, McNamara PJ, El-Khuffash AF. Non-pharmacological management of a hemodynamically significant patent ductus arteriosus. Semin Fetal Neonatal Med 2018;23:245-9.

7. Huang HS, Chang HH. Platelets in inflammation and immune modulations: functions beyond hemostasis. Arch Immunol Ther Exp (Warsz) 2012;60:443-51.

8. Leslie M. Cell biology. Beyond clotting: the powers of platelets. Science 2010;328:562-4.

9. Echtler K, Stark K, Lorenz M, et al. Platelets contribute to postnatal occlusion of the ductus arteriosus. Nat Med 2010;16:75-82.

10. Dani C, Poggi C, Fontanelli G. Relationship between platelet count and volume and spontaneous and pharmacological closure of ductus arteriosus in preterm infants. Am J Perinatol 2013;30:359-64.

11. Shah NA, Hills NK, Waleh N, et al. Relationship between circulating platelet counts and ductus arteriosus patency after indomethacin treatment. J Pediatr 2011;158:919-23.e1-2.

12. Akar S, Karadag N, Yildirim TG, et al. Does platelet mass influence the effectiveness of ibuprofen treatment for patent ductus arteriosus in preterm infants?. J Matern Fetal Neonatal Med 2016;29:3786-9.

13. Kahvecioglu D, Erdeve O, Akduman H, et al. Influence of platelet count, platelet mass index, and platelet function on the spontaneous closure of ductus arteriosus in the prematurity. Pediatr Neonatol 2018;59:53-7.

14. Wu X, Cai B, Su Z, Li Y, Xu J, Deng R, et al. Aspartate transaminase to platelet ratio index and gamma-glutamyl transpeptidase-to-platelet ratio outweigh fibrosis index based on four factors and red cell distribution width-platelet ratio in diagnosing liver fibrosis and inflammation in chronic hepatitis B. J Clin Lab Anal 2018;32:e22341.

15. Chen YP, Hu XM, Liang XE, Huang LW, Zhu YF, Hou JL. Stepwise application of fibrosis index based on four factors, red cell distribution width-platelet ratio, and aspartate aminotransferase-platelet ratio for compensated hepatitis B fibrosis detection. J Gastroenterol Hepatol 2018;33:256-63.
16. Faul F, Erdfelder E, Buchner A, Lang AG. Statistical power analyses using G*Power 3.1: Tests for correlation and regression analyses. Behavior Research Methods 2009;41:1149-60.

17. Ohlsson A, Shah PS. Paracetamol (acetaminophen) for patent ductus arteriosus in preterm or low birth weight infants. Cochrane Database Syst Rev 2018;4:CD010061.

18. Oshima A, Matsumura S, Iwatani A, et al. Safety and Feasibility of Intravenous Paracetamol for Patent Ductus Arteriosus in Indomethacin-/ Ibuprofen-Resistant or -Contraindicated Preterm Infants: A Case Series. AJP Rep 2020;10:e49-e53.

19. Hung YC, Yeh JL, Hsu JH. Molecular Mechanisms for Regulating Postnatal Ductus Arteriosus Closure. Int J Mol Sci 2018;19.pii: E1861.

20. Kasirer-Friede A, Kahn ML, Shattil SJ. Platelet integrins and immunoreceptors. Immunol Rev 2007;218:247-64.

21. Slomp J, Gittenberger-de Groot AC, Glukhova MA, Conny van Munsteren J, Kockx MM, Schwartz SM, et al. Differentiation, dedifferentiation, and apoptosis of smooth muscle cells during the development of the human ductus arteriosus. Arterioscler Thromb Vasc Biol 1997;17:1003-9.

22. Andrew M, Vegh P, Caco C, et al. A randomized, controlled trial of platelet transfusions in thrombocytopenic premature infants. J Pediatr 1993;123:285-91.

23. Bussel JB, Zacharoulis S, Kramer K, McFarland JG, Pauliny J, Kaplan C. Clinical and diagnostic comparison of neonatal alloimmune thrombocytopenia to non-immune cases of thrombocytopenia. Pediatr Blood Cancer 2005;45:176-83.

24. Simon SR, van Zogchel L, Bas-Suarez MP, Cavallaro G, Clyman RI, Villamor E. Platelet counts and patent ductus arteriosus in preterm infants: a systematic review and meta-analysis. Neonatology 2015;108:143-51.

25. Mitra S, Chan AK, Paes BA, Thrombosis and Hemostasis in Newborns (THIN) Group. The association of platelets with failed patent ductus arteriosus closure after a primary course of indomethacin or ibuprofen: a systematic review and meta-analysis. J Matern Fetal Neonatal Med 2017;30:127-33.

26. Sallmon H, Weber SC, Huning B, et al. Thrombocytopenia in the first $24 \mathrm{~h}$ after birth and incidence of patent ductus arteriosus. Pediatrics 2012;130:e623-30

27. Fujioka K, Morioka I, Miwa A, et al. Does thrombocytopenia contribute to patent ductus arteriosus?. Nat Med 2011;17:29-30.

28. Bekmez BO, Tayman C, Buyuktiryaki M, Cetinkaya AK, Cakır U, Derme T. A promising, novel index in the diagnosis and follow-up of patent ductus arteriosus: Red cell distribution width-to-platelet ratio. J Clin Lab Anal 2018;32:e22616

29. Bas-Suarez MP, Gonzalez-Luis GE, Saavedra P, Villamor E. Platelet counts in the first seven days of life and patent ductus arteriosus in preterm very low-birthweight infants. Neonatology 2014;106:188-94.

30. Murphy DP, Lee HC, Payton KS, Powers RJ. Platelet count and associated morbidities in VLBW infants with pharmacologically treated patent ductus arteriosus. J Matern Fetal Neonatal Med 2016;29:2045-8.

31. Brunner B, Hoeck M, Schermer E, Streif W, Kiechl-Kohlendorfer U. Patent ductus arteriosus, low platelets, cyclooxygenase inhibitors, and intraventricular hemorrhage in very low birth weight preterm infants. J Pediatr 2013;163:23-8. 
32. Kulkarni VV, Dutta S, Sundaram V, Saini SS. Preterm thrombocytopenia and delay of ductus arteriosus closure. Pediatrics 2016;1384:e20161627.

33. Meinarde L, Hillman M, Rizzotti A, Basquiera AL, Tabares A, Cuestas E. C-reactive protein, platelets, and patent ductus arteriosus. Platelets. 2016;27:821-3.

34. Bohrer B, Silveira RC, Neto EC, Procianoy RS. Mechanical ventilation of newborns infant changes in plasma pro- and anti-inflammatory cytokines. $\mathrm{J}$ Pediatr 2010;156:16-9.

35. Gerday E, Baer VL, Lambert DK, et al. Testing platelet mass versus platelet count to guide platelet transfusions in the neonatal intensive care unit. Transfusion 2009;49:2034-9.

36. Kamath S, Blann AD, Lip GY. Platelet activation: assessment and quantification. Eur Heart J 2001;22:1561-71.

37. Zisk JL, Mackley A, Clearly G, Chang E, Christensen RD, Paul DA. Transfusing neonates based on platelet count vs. platelet mass: A randomized feasibility-pilot study. Platelets 2014;25:513-6.

38. Israels SJ, Rand ML, Michelson AD. Neonatal platelet function. Semin Thromb Hemost 2003;29:363-72.

39. Strauss T, Sidlik-Muskatel R, Kenet G. Developmental hemostasis: primary hemostasis and evaluation of platelet function in neonates. Semin Fetal Neonatal Med 2011;16:301-4.

40. Becchi C, Al Malyan M, Fabbri LP, Marsili M, Boddi V, Boncinelli S. Mean platelet volume trend in sepsis: is it a useful parameter?. Minerva Anestesiol. 2006;72:749-56.

41. Akpek M, Kaya MG, Yarlioglues M, et al. Relationship between platelet indices and spontaneous echo contrast in patients with mitral stenosis. Eur J Echocardiogr 2011;12:865-70.

42. Erdogan D, Tayyar S, Icli A, et al. Elevated mean platelet volume is associated with impaired coronary microvascular function in patients with idiopathic dilated cardiomyopathy. Platelets 2012;23:177-83.

43. O'Malley T, Langhorne P, Elton RA, Stewart C. Platelet size in stroke patients. Stroke 1995;26:995-9.

44. Varol E, Uysal BA, Ozaydin M. Platelet indices in patients with pulmonary arterial hypertension. Clin Appl Thromb Hemost. 2011;17:E171-4.

45. Canpolat FE, Yurdakok M, Armangil D, Yiğit S. Mean platelet volume in neonatal respiratory distress syndrome. Pediatr Int 2009;51:314-6.

46. Dani C, Poggi C, Barp J, Berti E, Fontanelli G. Mean platelet volume and risk of bronchopulmonary dysplasia and intraventricular hemorrhage in extremely preterm infants. Am J Perinatol 2011;28:551-6.
47. Patrick CH, Lazarchick J, Stubbs T, Pittard WB. Mean platelet volume and platelet distribution width in the neonate. Am J Pediatr Hematol Oncol 1987;9:130-2.

48. Demirel G, Yilmaz A, Vatansever B, Tastekin A. Is high platelet distribution width in the first hours of life can predict hemodynamically significant patent ductus arteriosus in preterm newborns?. The Journal of MaternalFetal \& Neonatal Medicine, DOI: 10.1080/14767058.2018.1536743

49. Demir N, Peker E, Ece I, Agengin K, Bulan KA, Tuncer O. Is platelet mass a more significant indicator than platelet count of closure of patent ductus arteriosus? J Matern Fetal Neonatal Med 2016;29:1915-18.

50. Ahamed MF, Verma P, Lee S, et al. Predictors of successful closure of patent ductus arteriosus with indomethacin. J Perinatol 2015;35:729-34.

51. Kim ES, Kim EK, Choi CW, et al. Intrauterine inflammation as a risk factor for persistent ductus arteriosus patency after cyclooxygenase inhibition in extremely low birth weight infants. J Pediatr 2010;157:745-50.e1.

52. Olsson KW, Larsson A, Jonzon A, Sindelar R. Exploration of potential biochemical markers for persistence of patent ductus arteriosus in preterm infants at 22-27 weeks' gestation. Pediatr Res doi: 10.1038/s41390-0180182-x.

53. Yčas JW, Horrow JC, Horne BD. Persistent increase in red cell size distribution width after acute diseases: a biomarker of hypoxemia?. Clin Chim Acta 2015;448:107-17.

54. Chang BA, Huang Q, Quan J, et al. Early inflammation in the absence of overt infection in preterm neonates exposed to intensive care. Cytokine 2011;56:621-6.

55. Sola-Visner M, Sallmon H, Brown R. New insights into the mechanisms of nonimmune thrombocytopenia in neonates. Semin Perinatol 2009;33:4351 .

56. Sallmon H, Sola-Visner M. Clinical and research issues in neonatal anemia and thrombocytopenia. Curr Opin Pediatr 2012;24:16-22.

57. Itabashi $\mathrm{K}$, Ohno $\mathrm{T}$, Nishida $\mathrm{H}$. Indomethacin responsiveness of patent ductus arteriosus and renal abnormalities in preterm infants treated with indomethacin. J Pediatr 2003;143:203-7.

58. Nadkarni J, Patne SK, Kispotta R. Hypoxia as a predisposing factor for the development of early onset neonatal thrombocytopenia. J Clin Neonatol 2012;1:131-4.

59. Christensen RD, Baer VL, Yaish HM. Thrombocytopenia in late preterm and term neonates after perinatal asphyxia. Transfusion 2015;55:187-96.

60. Herdy GV, Lopes VG, Aragão ML, et al. Perinatal asphyxia and heart problems [in Portugese]. Arq Bras Cardiol 1998;71:121-6. 